\title{
Effects of dietary inclusion of Spirulina meal on growth and hematological parameters of cultured Asian sea bass, Lates calcarifer
}

\author{
Tan Chin Yong ${ }^{1}$, German Bueno Galaz ${ }^{2}$ and Rossita Shapawi ${ }^{*}$ \\ ${ }^{1}$ Borneo Marine Research Institute, Universiti Malaysia Sabah, 88400 Kota Kinabalu, Sabah, Malaysia \\ ${ }^{2}$ Facultad de Recursos, Naturales Renovables, Arturo Prat University, Iquique Tarapaca, Chile
}

*Corresponding author: rossita@ums.edu.my

\begin{abstract}
This study was conducted to investigate the effects of dietary inclusion of Spirulina platensis on growth performance and hematological parameters of juvenile Asian sea bass (Lates calcarifer) reared in a freshwater culture system. Five experimental diets were prepared by replacing fish meal protein with the microalga at replacement levels of 5\% (SP5), 10\% (SP10), 20\% (SP20) and 30\% (SP30), and the substitution effect was compared with a control diet (Con) in which fish meal was the sole protein. Fish were stocked in net cages placed in a 150-ton tank with a stocking density of 20 fish per cage. After 8 weeks of feeding trial, the fish did not show any significant differences in growth performance but numerically higher weight gain and specific growth rate were achieved in the fish stock fed diet SP10 compared to other treatments. Feed conversion ratio and survival rate of fish were significantly affected by the inclusion of Spirulina in the diets. Except for crude ash content, wholebody proximate composition of the experimental fish was also significantly influenced by the diets. Regarding the effects of diets on blood parameters, only hematocrit, hemaglobin, HDL-c and AST were significantly affected by the inclusion of Spirulina in the diets. This study demonstrated that Spirulina could replace up to $10 \%$ of FM protein in practical diets of juvenile Asian sea bass without negative effects on growth performance. However, replacement of fish meal with Spirulina meal at $5 \%$ might be considered for commercial use considering a significant decrease in survival above this value.
\end{abstract}

Keywords: Asian seabass, Spirulina, Replacement, Fish meal

\section{Introduction}

Asian sea bass, Lates calcarifer (Bloch 1790), is widely cultured in Asian countries including Malaysia. It is one of the most sought-after marine fish for commercial culture because of high market potential, fast growth, euryhaline nature and easy rearing of fry to adult size in the hatchery (Copland and Grey 1986). Asian sea bass can be cultured in marine, brackish or freshwater (Harpaz et al., 2005). Because the fish is predatory, it requires high-protein diet. The use of fishmeal (FM) is estimated to be more than $50 \%$ of the variable cost in sea bass feed (Woods, 1999). The industry largely depends on FM as a major protein source in aquafeeds due to its contents of essential nutrients such as indispensable amino acids, essential fatty acids, vitamins, minerals, attractants and unknown growth factors (Zhou et al., 2004). However, for reasons of environmental compatibility efforts are being made to lessen the dependency on FM.

Spirulina is one of the most common microalgae in warm saline and alkaline waters. Its growth rate under culture conditions is fast, almost like yeasts and many bacteria (Richmond, 1988). With a short life cycle, the Spirulina can duplicate its biomass in 3-5 days and has a

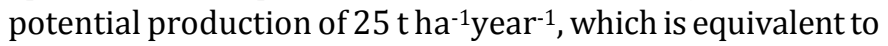
15 t of protein ha-1year-1(Richmond, 1988; Göhl, 1991). Spirulina platensis does not have cellulose cell wall. Its cells have mucopolymer murein that is easily hydrolyzed by the digestive enzymes of the fish (Beresto, 2001). It is a rich source of vitamins, essential amino acids, minerals, essential fatty acids ( $\gamma$-linolenic acid), and antioxidant pigments such as carotenoids and phycocyanin (Jaime-Ceballos et al., 2006) and can serves as an excellent source of proteins and other nutrients (Nandeesha et al., 1998). It has been included in the diets for silver seabream (Rhabdosargus sarba) (ElSayed, 1994); tilapia (Oreochromis mossambicus) (OlveraNovoa et al., 1998), sturgeon (Acipenser baeri) (Palmegiano et al., 2005) and common carp (Cyprinus carpio) (Nandeesha et al., 1998; Ramakrishnan et al., 2008) with promising results. More research is necessary to investigate the potential of this alga in promoting growth and survival of other fish species. Thus, the present study was conducted to evaluate the use of Spirulina platensis as a fish meal replacement in practical diets for Asian sea bass juveniles using a simple mixture of two protein sources in a freshwater recirculating system.

\section{Materials and Methods}

\section{Experimental diets}

Experimental diets were formulated to be isonitrogenous and isocaloric in terms of crude protein (45\%) and gross energy $\left(17.97 \mathrm{MJ} / \mathrm{kg}^{-1}\right)$. The energy value of the experimental diets was estimated on the basis of mammalian physiological fuel 
value, i.e., $16.7 \mathrm{KJg}^{-1}$ protein or carbohydrate and $37.7 \mathrm{KJg}^{-1}$ lipid (Lee and Putnam, 1973). Five experimental diets (Table 1) were formulated to contain $0 \%, 5 \%, 10 \%, 20 \%$ and $30 \%$ Spirulina meal, designated by Control, SP5, SP10, SP20, SP30, respectively. Spirulina meal was purchased from Vedan Biotechnology Corp (Taichung, Taiwan). All the ingredients were thoroughly mixed with $40 \%$ distilled water to become dough. Pellets were extruded through a meat chopper machine (Orimas TBS-200, Taiwan) in $3.0 \mathrm{~mm}$ diameter size, oven-dried at $40^{\circ} \mathrm{C}$ and stored at $-20^{\circ} \mathrm{C}$ until use.

Table 1. Composition of the experimental diets

\begin{tabular}{llllll}
\hline Ingredients & Diets & & & & \\
\cline { 2 - 6 } & Con & SP5 & SP10 & SP20 & SP30 \\
\hline Fish Meala $^{\mathrm{a}}$ & 59.93 & 56.93 & 53.94 & 47.94 & 41.95 \\
Spirulina $^{\mathrm{b}}$ & 0.0 & 3.34 & 6.68 & 13.37 & 20.05 \\
Fish Oilc $^{V_{\text {Vitamin mix }}^{\mathrm{d}}}$ & 6.56 & 6.84 & 7.11 & 7.65 & 8.19 \\
Mineral mix $^{\mathrm{e}}$ & 2.00 & 3.00 & 3.00 & 3.00 & 3.00 \\
$\begin{array}{l}\text { Dicalcium } \\
\text { phosphate }\end{array}$ & 1.00 & 2.00 & 2.00 & 2.00 & 2.00 \\
$\begin{array}{l}\text { Carboxymethyl } \\
\text { celluloseg }\end{array}$ & 1.50 & 1.00 & 1.00 & 1.00 & 1.00 \\
$\begin{array}{l}\text { Tapioca } \\
\text { starch }\end{array}$ & 20.00 & 20.00 & 20.00 & 20.00 & 20.00 \\
$\alpha-$ Cellulose $^{\mathrm{i}}$ & 6.01 & 5.39 & 4.78 & 3.54 & 2.31
\end{tabular}

Proximate

composition

(\% DM)

Moisture

Protein 8.30

Lipid 44.55

11.74

Ash

12.18

18.92

8.20
43.88
11.83
12.04
18,83

8.40

$17.15 \quad 16.64$

$\begin{array}{lll}43.25 & 44.47 \quad 46.90\end{array}$

$\begin{array}{lll}12.02 & 12.49 & 12.82\end{array}$

$\begin{array}{lll}12.03 & 11.38 & 11.30\end{array}$

Energy

18,83

$\begin{array}{lll}18.62 & 18.02 & 17.59\end{array}$

\begin{tabular}{lllllc}
$(\mathrm{MJ} / \mathrm{kg})$ & & & & & \\
\hline $\begin{array}{l}\text { Major } \\
\text { Ingredients }\end{array}$ & Moisture & Protein & Lipid & Ash & $\mathrm{NFE}^{1}$ \\
\hline Fish Meal & 8.79 & 75.09 & 9.07 & 13.39 & --- \\
Spirulina & 4.66 & 67.34 & 0.03 & 8.0 & 19.97 \\
\hline
\end{tabular}

a Danish fish meal, Denmark

b Spirulina was provided Vedan Biotechnology Corp (Taichung, Taiwan)

c Dexchem Industries Sdn. Bhd, Malaysia

d Vitamin premix. Contained (as g kg-1): ascorbic acid, 300; inositol, 125; niacin, 50; riboflavin, 15; pyridoxine, 12; thiamin mononitrite, 15 ; retinyl acetate, 1.72 ;

cholecalciferol, 0.025 ; menadione sodium bisulphite, 5 ; biotin, 0.5 ; folic acid, 2.5 ; DL$\alpha$-tocopheryl acetate, 50; vitamin B12, 0.025; calpan, 25. Dexchem Industries Sdn. Bhd, Malaysia

e Mineral premix. Contained (as g kg-1): calcium phosphate-H2O (MDCP), 397.65 calcium lactate, 327 ; ferrous sulphate $\cdot \mathrm{H} 2 \mathrm{O}, 25$; magnesium sulphate $7 \mathrm{H} 2 \mathrm{O}, 137$; potassium chloride, 50 ; sodium chloride, 60 ; potassium iodide, 0.15 ; copper sulphate $5 \mathrm{H} 2 \mathrm{O}, 0.785$; manganese oxide, 0.8 ; cobalt carbonate, 0.1 ; zinc oxide, 1.5 ; sodium selenite 5 H20, 0.02. Dexchem Industries Sdn. Bhd, Malaysia

f Merck, 64271 Darmstadt, Germany

g EMD Chemicals, Inc. San Diego, CA

h AAA Brand, Bake With Me Sdn. Bhd., Malaysia

i Sigma-Aldrich Corporation, USA

${ }^{1}$ Nitrogen Free Extracts $=100-(\%$ Moisture+\%CP+\%Lipid $+\%$ Ash $)$.

\section{Fish, facilities and feeding trial}

The feeding trial was carried out at the hatchery facilities at Borneo Marine Research Institute of Universiti Malaysia Sabah (UMS). Asian sea bass juveniles were obtained from the hatchery. The fish were acclimatized to experimental rearing conditions and weaned to the formulated diets for two weeks with a commercial feed (Cargill Feed SDN. BHD. Ltd., Melaka, Malaysia) (45\% crude protein and 8\% crude lipid), prior to the feeding trials. Three hundred fish of initial body weight (BW) of $6.02 \pm 0.03$ g were randomly distributed into groups of 20 fish in 15 cylindrical cages, each measuring $41 \mathrm{~cm}$ depth and $52 \mathrm{~cm}$ diameter, and placed in a 150 ton FRP (fibreglass reinforced plastic) tank equipped with a water recirculation system using dechlorinated tap water and coral rubble as filter. Around $20-30 \%$ of water was exchanged daily during bottom cleaning. Water quality was maintained at a temperature of $28.12 \pm 0.29^{\circ} \mathrm{C}$, dissolved oxygen (DO) at 6.80 $\pm 0.13 \mathrm{mg} / \mathrm{L}$ and $\mathrm{pH}$ at $7.89 \pm 0.25$. The fish were fed till apparent satiation twice a day (9:00 and 14:00 h), seven days a week, for 8 weeks. The growth of fish was measured at every 2 -week interval. Feeding was terminated 24 hours prior to weighing.

\section{Sample collection and analysis}

At the beginning and the end of the feeding trial, all the fish specimens were bulk-weighed, counted, and their total and fork lengths were measured for calculation of weight gain (WG), specific growth rate (SGR), protein efficiency ratio (PER), feed conversion ratio (FCR), condition factor (CF) and survival. Three fish per cage (nine fish per dietary treatment) were collected for whole-body proximate analysis. Proximate composition of diets and whole-body fish were determined following the AOAC (1995) method. Crude protein was measured by using automatic Kjeltec Analyzer Unit 2300 (FOSS, Sweden) and crude lipid was determined by petroleum benzene extraction method using Soxtec ${ }^{\mathrm{TM}} 2043$, hot extraction (FOSS Tecator, Sweden). Crude ash content was determined as the residue remaining after incineration of dry samples at $550{ }^{\circ} \mathrm{C}$ in a muffle furnace for 6 hours. Samples of the diets were assayed for gross energy (GE) by C5003 IKA adiabatic oxygen bomb calorimeter (GMBIT and Co., Dresden, Germany).

At the end of the feeding trial blood samples of six randomly selected fish from each cage (eighteen fish per treatment) were collected from the caudal vein using nonheparinized syringe for determination of hematological and biochemical parameters. For hematological examination $1 \mathrm{ml}$ of fish blood was placed inside K3 EDTA tubes. EDTA tubes have interior walls coated with K3 EDTA. EDTA binds calcium ions and blocks the coagulation cascade (Greiner Bio-One $®$ ). Afterwards the tubes were placed in a Sysmex XT-1800i machine for hematocrit and hemoglobin measurements. For biochemical parameters $2 \mathrm{ml}$ of fish blood was placed inside Z Serum Sep Clot Activator tubes (Greiner Bio-One $囚)$, followed by centrifugation at $35 \times 100 \mathrm{rpm}$ for 10 minutes in a Kubota 2420 centrifuge and placed in a cobas $₫ 501$ analyzer (Roche Diagnostics, Indianapolis, IN) for total protein, cholesterol, cholesterol HDL, cholesterol LDL, triglyceride, alanine amino transferase and aspartate amino transferase measurements.

Another group of three fish was randomly selected from each cage for determination of hepatosomatic index (HSI) and viscerosomatic index (VSI). 


\section{Amino acid analysis}

Diet samples were hydrolysed in triplicate with $6 \mathrm{~N} \mathrm{HCl}$ for 24 hours at $110^{\circ} \mathrm{C}$. Sample was derivatized by using post column derivatizer (PCX 5200, Pickering Laboratories, USA). The reagents used for post column derivatization are $o$ Phthalaldehyde (OPA) and Thiofluor ${ }^{\mathrm{TM}}$ in $\mathrm{pH} 10.4$ borate buffer (OPA diluents for Amino Acid analysis) $+30 \mathrm{~mL}$ Brij $35^{\circledR}$ (Pickering Laboratories, USA). Chromatographic separation was done using a High Efficiency Sodium CationExchange column $(5 \mu \mathrm{m}, 4.0 \mathrm{x} 150 \mathrm{~mm}$, Pickering Laboratories, USA). The column temperature is set at $53^{\circ} \mathrm{C}$ while the reactor temperature at $45^{\circ} \mathrm{C}$. Flow rate was set at $0.4 \mathrm{~mL} /$ minute. The HPLC system used is a system controller (SCL-10A), liquid chromatograph (LC-10AD), degasser (DGU$14 \mathrm{~A}$ ), fluorescence detector (wavelength excitation at $330 \mathrm{~nm}$, emission at $365 \mathrm{~nm}$ ) and an auto injector (SIL-10AD, Shimadzu, Japan). The mobile phases used were acidic buffer (Sodium eluant, pH 3.15, with 5\% Silfolane), neutral buffer (Sodium eluant, pH 7.40) and Sodium column regenerant. Chromatographic peaks were integrated, identified and quantified with Class-VP Ver. 6.1 (Shimadzu) by comparing with the known standards (amino acid protein hydrolysate standard, in $0.2 \mathrm{~N}$ sodium citrate buffer $\mathrm{pH} 2.20,0.25 \mu$ mole $\mathrm{mL}^{-1}$ (Pickering Laboratories, USA). Methionine and cystine were determined from the same method of acid hydrolysis.

\section{Statistical analysis}

Data was subjected to one-way ANOVA in SPSS version 11.0. Significant differences between group means were compared using Duncan's multiple test. Data presented are means \pm standard deviation (SD). Data with percentage values were arcsine transformed before the ANOVA analysis. Differences were considered significant at $\mathrm{p}<0.05$.

\section{Results}

Table 2 shows the amino acid composition of experimental diets. In general, the inclusion of Spirulina in the diets did not appreciably alter the amino acid profile of the diets. A slight reduction of methionine was observed when Spirulina inclusion was increased in the diets. Growth performance and feed utilization of fish fed the experimental diets are presented in Table 3. At the end of the eight-week feeding trial, there were no significant differences in final body weight, weight gain, specific growth rate and protein efficiency ratio of fish fed the experimental diets. Feed conversion ratio was significantly affected when fish meal was replaced with Spirulina meal at 30\% replacement level. FCR for other diets ranged from 1.31-1.83 as compared to 2.97 in SP30. Similarly, the lowest feed intake was also observed in SP30. However, no significant difference was observed in protein efficiency ratio, but the highest value of PER was found in SP10. The net protein utilization was also numerically higher in fish fed SP10 diet compared to the fish offered the control diet and was also significantly higher compared to dietary treatment SP30. Survival was significantly lower in fish fed diets SP20 (60\%) and SP30 (55\%) compared to that of fish fed the control diet (96.67\%). Table 4 shows the whole-body proximate composition and body indices of juvenile Asian seabass. Except for crude ash content, dietary treatments significantly influenced the whole body composition of the fish. Lipid content was significantly higher in fish fed diet SP5 compared to the fish fed the control diet. Increasing levels of spirulina inclusion in diets resulted in a decreasing trend in whole body lipid of the experimental fish. Hepato-somatic index was significantly higher in fish fed diets SP30 and SP20 compared to its value in the fish fed the control diet. No significant differences were found in the condition factor and viscera-somatic index of the fish fed all the experimental diets.

Table 2. Amino acid composition of experimental diets (\%)

\begin{tabular}{llllll}
\hline Amino acid & SP0 & SP 5 & SP 10 & SP 20 & SP 30 \\
\hline Aspartic acid & 4.52 & 4.30 & 4.17 & 4.17 & 4.51 \\
Threonine & 1.88 & 1.99 & 1.94 & 1.96 & 2.14 \\
Serine & 2.14 & 2.05 & 2.02 & 2.07 & 2.23 \\
Glutamic acid & 6.50 & 6.33 & 6.14 & 6.17 & 6.67 \\
Glycine & 3.12 & 3.24 & 3.25 & 3.30 & 3.30 \\
Alanine & 3.15 & 2.99 & 2.96 & 3.05 & 3.28 \\
Cystine & 2.27 & 2.16 & 2.11 & 2.17 & 2.39 \\
Methionine & 1.33 & 1.26 & 1.21 & 1.15 & 1.20 \\
Isoleucine & 2.10 & 2.03 & 2.02 & 2.16 & 2.37 \\
Leucine & 3.80 & 3.67 & 3.68 & 3.82 & 4.04 \\
Tyrosine & 1.31 & 1.27 & 1.32 & 1.38 & 1.57 \\
Phenylalanine & 1.92 & 1.65 & 1.64 & 1.69 & 1.86 \\
Lysine & 4.17 & 4.30 & 4.34 & 4.43 & 4.13 \\
Arginine & 3.10 & 3.07 & 3.11 & 3.27 & 3.45 \\
\hline
\end{tabular}

Hematocrit in fish fed diet SP30 was lowest among the dietary treatments. No significant differences were observed in hematocrit in other fish groups. Inclusion of Spirulina at $30 \%$ (SP30) also resulted in lower hemoglobin and high density lipoprotein cholesterol (HDL-c) compared to other treatments. On the other hand, aspartate amino transferase (AST) in fish fed diet SP30 was the highest among the dietary treatments. No significant differences were observed in total protein, total tryglyceride (TG), total cholesterol (T-Cho), low density lipoprotein cholesterol (LDL-c) and alanine aminotransferase (ALT) as a result of Spirulina inclusion in the diets (Table 5). 
Table 3. Growth performance of Asian sea bass (Lates calcarifer) fed the experimental diets

\begin{tabular}{llllll}
\hline Diets & Con & SP5 & SP10 & SP20 & SP30 \\
\hline Initial Body Weight (g) & $6.02 \pm 0.02$ & $6.02 \pm 0.01$ & $6.02 \pm 0.01$ & $5.98 \pm 0.03$ & $6.05 \pm 0.004$ \\
Final Body Weight (g) & $15.15 \pm 2.53$ & $17.71 \pm 1.17$ & $18.17 \pm 1.94$ & $16.05 \pm 4.21$ & $12.64 \pm 3.24$ \\
Weight gain (\%) $^{\mathrm{a}}$ & $151.48 \pm 41.46$ & $194.24 \pm 19,28$ & $201.65 \pm 32,33$ & $168.37 \pm 71.10$ & $109.10 \pm 53.72$ \\
${\text { Specific growth rate }\left(\% \mathrm{~d}^{-1}\right)^{\mathrm{b}}}$ & $1.60 \pm 0.31$ & $1.89 \pm 0.11$ & $1.93 \pm 0.18$ & $1.68 \pm 0.51$ & $1.26 \pm 0.44$ \\
Feed conversion ratio $^{\mathrm{e}}$ & $1.83 \pm 0.29 \mathrm{ab}$ & $1.66 \pm 0.24 \mathrm{ab}$ & $1.61 \pm 0.04^{\mathrm{a}}$ & $1.31 \pm 0.86^{\mathrm{a}}$ & $2.97 \pm 1.23^{\mathrm{b}}$ \\
Feed intake (g) $^{\mathrm{f}}$ & $0.27 \pm 0.04^{\mathrm{ab}}$ & $0.30 \pm 0.01^{\mathrm{b}}$ & $0.29 \pm 0.05^{\mathrm{b}}$ & $0.25 \pm 0.01^{\mathrm{ab}}$ & $0.21 \pm 0.04^{\mathrm{a}}$ \\
Protein efficiency ratio $^{\mathrm{c}}$ & $1.33 \pm 0.13$ & $1.60 \pm 0.07$ & $1.74 \pm 0.05$ & $1.62 \pm 0.36$ & $1.14 \pm 0.21$ \\
Net protein utilization $^{\mathrm{d}}$ & $18.46 \pm 1.48^{\mathrm{ab}}$ & $21.64 \pm 1.54 \mathrm{ab}$ & $26.90 \pm 1.20^{\mathrm{b}}$ & $19.02 \pm 5.29 \mathrm{ab}$ & $20.00 \pm 3.58^{\mathrm{a}}$ \\
Survival (\%) & $96.67 \pm 2.89^{\mathrm{c}}$ & $83.33 \pm 10.41^{\mathrm{bc}}$ & $73.33 \pm 7.64^{\mathrm{ab}}$ & $55.00 \pm 13.23^{\mathrm{a}}$ & $60.00 \pm 18.03^{\mathrm{a}}$ \\
\hline
\end{tabular}

Table 4. Whole-body composition (\% wet weight basis) and body indices of juvenile Asian sea bass fed experimental diets

\begin{tabular}{|c|c|c|c|c|c|c|}
\hline \multirow[t]{2}{*}{ Parameters } & \multirow{2}{*}{ Initial } & \multicolumn{5}{|l|}{ Diet group } \\
\hline & & Con & SP5 & SP10 & SP20 & SP30 \\
\hline Moisture & $73.81 \pm 0.82^{\mathrm{ab}}$ & $73.80 \pm 0.94 \mathrm{ab}$ & $72.81 \pm 1.13^{a}$ & $73.92 \pm 0.58^{\mathrm{ab}}$ & $76.04 \pm 0.44 c$ & $75.25 \pm 1.13^{b c}$ \\
\hline Crude Protein & $17.66 \pm 0.09 \mathrm{e}$ & $15.77 \pm 0.60^{b c}$ & $15.56 \pm 0.38^{\mathrm{ab}}$ & $16.62 \pm 0.47 \mathrm{~d}$ & $15.08 \pm 0.22^{\mathrm{a}}$ & $16.40 \pm 0.04 \mathrm{~cd}$ \\
\hline Crude Lipid & $3.49 \pm 0.39 \mathrm{ab}$ & $5.03 \pm 0.53^{c}$ & $6.12 \pm 0.81^{d}$ & $4.37 \pm 0.34 \mathrm{bc}$ & $2.91 \pm 0.20^{\mathrm{a}}$ & $2.62 \pm 0.87 \mathrm{a}$ \\
\hline Ash & $4.35 \pm 0.01$ & $4.55 \pm 0.25$ & $4.36 \pm 0.17$ & $4.36 \pm 0.26$ & $4.66 \pm 0.23$ & $4.72 \pm 0.61$ \\
\hline \multicolumn{2}{|c|}{ Condition factor a } & $1.44 \pm 0.10$ & $1.38 \pm 0.13$ & $1.46 \pm 0.04$ & $1.36 \pm 0.10$ & $1.36 \pm 0.02$ \\
\hline \multicolumn{2}{|c|}{ Hepato-somatic index } & $0.82 \pm 0.10^{a}$ & $1.11 \pm 0.22^{\mathrm{ab}}$ & $1.27 \pm 0.12^{\mathrm{ab}}$ & $1.35 \pm 0.18^{b}$ & $1.53 \pm 0.47 b$ \\
\hline \multicolumn{2}{|c|}{ Vicero-somatic index ${ }^{c}$} & $5.10 \pm 1.10$ & $5.80 \pm 0.20$ & $5.82 \pm 0.39$ & $5.26 \pm 0.71$ & $5.85 \pm 1.42$ \\
\hline
\end{tabular}

Values are mean \pm standard deviation. Values in the same row with different letters are significantly different $(P<0.05)$

aCondition factor $=$ fish weight $(\mathrm{g}) \times 100 /$ fish length $(\mathrm{cm})^{3}$.

bHepatosomatic index $=100 \times$ (liver weight/body weight).

cVicerosomatic index $=100 \times$ (Vicera weight/body weight).

*Values are mean \pm standard deviation. Values in the same row with different letters are significantly different $(P<0.05)$.

Table 5. Blood parameters of juvenile Asian sea bass (Lates calcarifer) fed the experimental diets

\begin{tabular}{|c|c|c|c|c|c|}
\hline Diets & Con & SP5 & SP10 & SP20 & SP30 \\
\hline Hematocrit (\%) & $40.33 \pm 3.06^{\mathrm{ab}}$ & $44.00 \pm 4.00^{\mathrm{b}}$ & $46.00 \pm 4.58^{b}$ & $32.00 \pm 12.77 \mathrm{ab}$ & $22.00 \pm 18.36^{a}$ \\
\hline Hemoglobin $\left(\mathrm{g} \mathrm{dL}^{-1}\right)$ & $6.40 \pm 0.30^{\mathrm{b}}$ & $6.50 \pm 0.52^{\mathrm{b}}$ & $6.87 \pm 0.75^{b}$ & $5.73 \pm 1.85^{\mathrm{ab}}$ & $3.87 \pm 1.85^{\mathrm{a}}$ \\
\hline Total protein $\left(\mathrm{g} \mathrm{dL}^{-1}\right)$ & $3.30 \pm 0.60$ & $3.47 \pm 0.21$ & $3.53 \pm 0.21$ & $3.47 \pm 0.06$ & $3.43 \pm 0.12$ \\
\hline $\mathrm{TG}\left(\mathrm{mg} \mathrm{dL} \mathrm{L}^{-1}\right)^{\mathrm{a}}$ & $271.00 \pm 54.53$ & $183.00 \pm 35.00$ & $148.33 \pm 26.50$ & $285.33 \pm 123.62$ & $262.33 \pm 71.59$ \\
\hline T-Cho (mg dL-1)b & $294.67 \pm 68.16$ & $307.67 \pm 4.62$ & $317.67 \pm 10.97$ & $283.00 \pm 15.72$ & $258.67 \pm 13.28$ \\
\hline HDL-c $\left(\mathrm{mg} \mathrm{dL}^{-1}\right)^{\mathrm{c}}$ & $123.33 \pm 20.60^{a b}$ & $151.67 \pm 15.63 \mathrm{bc}$ & $171.00 \pm 22.52^{c}$ & $128.33 \pm 17.04^{a b}$ & $114.00 \pm 19.97 \mathrm{a}$ \\
\hline LDL-c $\left(\mathrm{mg} \mathrm{dL}^{-1}\right)^{\mathrm{d}}$ & $117.00 \pm 38.11$ & $118.00 \pm 9.54$ & $117.00 \pm 16.09$ & $97.33 \pm 2.31$ & $91.33 \pm 17.90$ \\
\hline $\operatorname{ALT}\left(U^{-1}\right)^{\mathrm{e}}$ & $16.67 \pm 12.22$ & $9.00 \pm 1.73$ & $9.00 \pm 1.73$ & $32.33 \pm 24.50$ & $18.33 \pm 5.69$ \\
\hline $\operatorname{AST}\left(\mathrm{U} \mathrm{L}^{-1}\right)^{\mathrm{f}}$ & $71.00 \pm 48.45^{\mathrm{ab}}$ & $37.67 \pm 8.08^{\mathrm{a}}$ & $39.33 \pm 10.69^{a}$ & $60.33 \pm 29.37 \mathrm{ab}$ & $99.67 \pm 33.08^{b}$ \\
\hline
\end{tabular}

a TG: triglyceride.

b T-Cho: total cholesterol.

c HDL-c: high density lipoprotein cholesterol.

d LDL-c: low density lipoprotein cholesterol.

e ALT : alanine aminotransferase, unit per liter $\left(\mathrm{U} \mathrm{L}^{-1}\right)$ is the amount of enzyme which oxidizes $1 \mu \mathrm{mol} \mathrm{L}^{-1}$ of NADH per minute.

f AST : aspartate aminotransferase

*Values are means \pm SE of triplicate groups. Within a row, means with the same letters are not significantly different $(\mathrm{P}>0.05)$.

\section{Discussion}

Spirulina has been successfully utilized alone or in combination with other protein sources to replace fish meal. It has been used to replace fish meal in the diet of Cyprinus carpio (Nandesha et al., 1998), Acipenser baeri (Palmegiano et al., 2005) and Oreochromis mossambicus (Olvera-Novoa et al., 1998), with successful replacement values of 100,60 and $40 \%$, respectively. The variation in results might be attributed to different Spirulina strains utilized or the variations in the ability of fish species to utilize the algae meal. The growth of Asian sea bass fed the experimental diets did not differ significantly $(P>0.05)$ in terms of WG, SGR and PER. Similarly, no significant effects have been reported on growth performance in common carp, Cyprinus carpio (Nandeesha et al., 1998) and catla Catla catla (Nandeesha et al., 2001). However, in this experiment the inclusion of spirulina in diet improved FCR with the exception of dietary treatment SP30. Similar trend was also observed for the NPU values. Survival rate of the fish was significantly affected as a result of cannibalism and low feed intake of fish offered high inclusion level of Spirulina in diet. Low feed intake is directly proportional to the protein intake, which in turn affects growth rate (Phumee et al., 2011). Observations made by Qin et al. (2004) also revealed that the cannibalism in Asian sea bass culture caused severe losses during the early stages of development particularly before fish reach a length of about $10 \mathrm{~cm}$. An individual Asian sea bass cannibal can swallow a sibling with a body length of $70 \%$ or less than its own. According to Appelbaum and Arockiaraj (2010), sibling cannibalism in juvenile Asian sea bass could begin when the body length of a cannibal reaches about one and half times that of the prey fish. Also, cannibalism may occur in spite of ad libitum feeding. 
Olvera-Novoa et al. (1998) reported low feed intake in tilapia when offered diets which contained increasing level of spirulina. This was attributed to increase in particle hardness and low palatability resulting from high spirulina content in the diet. Higher feed intake values obtained in diets SP5 and SP10 were reflected in improvement in growth, feed efficiency, health and immune parameters in fish groups fed by these two diets. On the other hand, fish fed diet SP30 (with the highest inclusion level of Spirulina) suffered impairment of growth and feed efficiency parameters as well as health condition as expressed by significantly lower values of hemoglobin and and hematocrit as compared to the fish fed the control diet. SP30 also exhibited a potential liver damage expressed by the numerically higher values for aspartate amino transferase (AST) compared to the fish fed the control diet and significantly higher in comparison with the fish fed the lowest inclusion level of spirulina SP5. The cellulose walls of Spirulina are made of digestible mucoproteins (Richmond, 1988) which have a digestibility of 83-84\% (Santillán, 1979). However, little information is available on the digestibility of Spirulina in fish diets. Olvera-Novoa et al. (1998) reported a reduction in digestibility with an increase of Spirulina inclusion in diets for tilapia $(82.55,81.92,69.85,78.17$, $46.00,45.45 \%$ apparent digestibility with an inclusion of 0 , $20,40,60,80,100 \%$ of Spirulina in diets, respectively). Ekpo and Bender (1989) reported a digestibility of $62 \%$ for a mixture of Cyanophyta consumed by Oreochromis niloticus in ponds. In this experiment, digestibility was not measured but reduced digestibility as the level of Spirulina increased is expected, especially at 30\% inclusion level.

In the present study, fish were reared in a freshwater recirculating system which is a common practice for commercial purposes. A large percentage of dietary salt in commercial feeds for carnivorous fish originates from the fish meal component of the diet (Murray and Andrews 1979). It is, therefore, important to take this into account when replacing fish meal with various plant-derived meals, which are not as rich in salt. Asian sea bass is very similar to other carnivorous fish in its nutritional requirements (Catacutan and Coloso, 1995; Catacutan and Coloso, 1997). The poor performance of fish fed the highest inclusion of Spirulina in the present study might suggest that the rearing of a marine fish such as Asian sea bass in a freshwater environment and at the same time, using diets in which fishmeal is replaced with plant protein sources could face a lack of some minerals needed for the passive outward flux of ions such as $\mathrm{Na}^{+}$and $\mathrm{Cl}^{-}$from the fish to the external medium. This must be overcome by active uptake of ions (e.g., $\mathrm{Na}^{+}, \mathrm{Cl}$; $\mathrm{K}^{+}$, and $\mathrm{Ca}^{2+}$ ) from the water and/or from the diet (Smith et al., 1989; Schmidt-Nielsen, 1997). The diet constitutes an important source of salts that can satisfy the osmoregulation requirements of fish maintained in freshwater where energy otherwise mobilized for osmoregulation is spared and becomes available for supporting growth (Zaugg et al., 1983; Gatlin et al., 1992). Previous study done on Asian sea bass showed that the addition of salt to the diet which resulted in a significant improvement in feed conversion ratio (FCR) had no effect on carcass composition of fish, although alkaline phosphatase, lactase, and, to some extent, leucine amino peptidase activity were enhanced, with most pronounced effect exhibited in the pyloric caeca (Harpaz et al. 2005). The contribution of salt to fish nutrition can be explained by a better enzymatic activity due to absorption mechanism of the end products, including glucose and amino acids. Since the glucose and most of the amino acid absorption depends on the $\mathrm{Na}^{+} / \mathrm{K}^{+}$ATPase pump (Klein et al., 1998), and higher concentration of $\mathrm{Na}^{+}$in the lumen might lead to a better absorption of carbohydrates and amino acids (De la Fuente et al., 1997). It is also interesting to note that the amino acid profile of the diets based on Spirulina did not significantly differ from the control diet, suggesting that the experimental diets were able to supply the necessary essential amino acids to the cultured fish.

In this study, fish fed SP20 and SP30 diets showed significantly higher HSI value than fish fed the control diet. However, different levels of Spirulina in the diets did not produce any significant difference in HSI of Acipenser baeri and Oplegnathus fasciatus (Palmegiano et al., 2005; Kim et al., 2013). The results of proximate composition analysis revealed significant increase in whole body protein content in fish fed SP10 diet. With the exception of the dietary treatment SP20, values were similar to those found for silver seabream (El-Sayed, 1994). On the contrary, Nandeesha et al. (1998), Palmegiano et al. (2005), and Tongsiri e al. (2010) did not find any significant differences in carcass composition of Cyprinus carpio, Acipenser baeri and Pangasianodon gigas. In the present study, fish fed SP20 and SP30 diets showed significantly lower whole-body lipid content than the fish fed the control diet. These results are in agreement with Mustafa et al. (1994) who found that dietary Spirulina supplementation was associated with a significant decrease in lipid level with a compensatory increase in moisture content. Similarly, in striped jack (Pseudocaranx dentex) it was found that the inclusion of 5\% Spirulina in diets resulted in depression of body lipid and improved growth rates (Liao et al., 1990; Watanabe et al., 1990).

\section{Conclusion}

In conclusion, Spirulina plantensis meal can be used as a source of protein in the diets for Asian sea bass cultured in freshwater environment. Diet SP10 showed higher values for growth performance, feed efficiency and the selected blood parameters. However, the results suggest that $5 \%$ fishmeal replacement by dietary inclusion of Spirulina meal might be optimum and a safe level for commercial use for the juvenile Asian sea bass. 


\section{References}

Appelbaum, S. \& Arockiaraj, A.J. (2010). Sibling cannibalism in juvenile Asian sea bass (Lates calcarifer) reared under different photoperiods. AACL Bioflux 3 (5), 384-392.

AOAC (Association of Official Analytical Chemists) (1990). Official methods of analysis. AOAC, Arlington, Virginia

Beresto, V. (2001). Our experience in spirulina feeding to minks in the reproduction period. Scientifur 25, 11-15.

Catacutan, M.R. \& Coloso, R.M. (1995). Effect of dietary protein to energy ratios on growth, survival, and body composition of juvenile Asian seabass Lates calcarifer. Aquaculture 131, 125- 133.

Catacutan, M.R. \& Coloso, R.M. (1997). Growth of juvenile Asian seabass, Lates calcarifer, fed varying carbohydrate and lipid levels. Aquaculture 149, 137- 144.

Copland, J. W. \& Grey, D. L. (1986). Management of wild and culture sea bass / barramundi (Lates calcarifer): Proceedings of an international workshop held at Darwin, N.T., Australia, 24-30 September 1986. ACIAR Proceedings No. 20, Australian Centre for International Agricultural Research, Canberra, Australia, $210 \mathrm{pp}$.

De la Fuente, J.L., Rumbero, A., Martín, J.F. \& Liras, P. (1997). DELTA-1piperideine-6-carboxylate dehydrogenase, a new enzyme that forms alphaaminoadipate in Streptomyces clavuligerus and other cephamycin Cproducing actinomycetes. Journal of Biochemical 327, 59-64.

Ekpo, I. \& Bender, J. (1989). Digestibility of a commercial fish feed, wet algae, and dried algae by Tilapia nilotica and silver carp. Progressive FishCulturist 51, 83-86.

El-Sayed, A.M. (1994). Evaluation of soybean meal, Spirulina meal and chicken offal meal as protein sources for silver seabream (Rhabdosargus sarba) fingerlings. Aquaculture 127, 169-176.

Gatlin III, D.M., MacKenzie, D.S., Craig, S.R. etal. (1992). Effects of dietary sodium chloride on red drum juveniles in waters of various salinities. Progressive Fish-Culturist 54, 220- 227.

Göhl, B. (1991). Tropical Feeds Version 1.7. FAO/Oxford Computer Journals Ltd, Oxford

Harpaz, S., Hakim, Y., Slosman, T. et al. (2005). Effects of adding salt to the diet of Asian sea bass Lates calcarifer, reared in fresh or salt water recirculating tanks, on growth and brush border enzyme activity. Aquaculture 248, 315-324.

Jaime-Ceballos, B.J., Hernández-Llamas, A., Garcia-Galano, T. et al. (2006). Substitution of Chaetoceros muelleri by Spirulina platensis meal in diets for Litopenaeus schmitti larvae. Aquaculture 260, 215-220.

Kim, S.S., Rahimnejad, S., Kim, K-W. et al. (2013). Partial Replacement of Fish Meal with Spirulina pacifica in Diets for Parrot Fish (Oplegnathus fasciatus). Turkish Journal of Fisheries and Aquatic Sciences 13, 197204.

Klein, S., Cohn, S.M. \& Alpers, D.H. (1998). The alimentary tract in nutrition. In: Modern Nutrition in Health and Disease, ninth edition (M.E. Shils, A.J. Olson, M. Shike, A.C. Ross, eds.), pp 605-630. Williams and Wilkins, Baltimore, MD.

Liao, W.L., Takeuchi, T., Watanabe, T. et al. (1990). Effect of dietary spirulina supplementation on extractive nitrogenous constituents and sensory test of cultured striped jack flesh. Journal of the Tokyo University of Fisheries 77, 241-256.

Murray, M.W. \& Andrews, J.W. (1979). Channel catfish: the absence of an effect of dietary salt on growth. Progressive Fish-Culturist 41, 155-156.

Mustafa, M.G., Umino, T., Miyake, H. et al. (1994). Effect of Spirulina sp. meal as feed additive on lipid accumulation in red sea bream, Pagrus major. Journal of Applied Ichthyology 10, 141-145.

Nandeesha, M.C., Gangadhara, B., Varghese, T.J. et al. (1998). Effect of feeding Spirulina platensis on the growth, proximate composition and organoleptic quality of common carp, Cyprinus carpio. Aquaculture Research 29, 305-312.

Nandeesha, M.C., Gangadhara, B., Manissery, J.K. et al. (2001). Growth performance of two Indian major carps, catla (Catla catla) and rohu (Labeo rohita) fed diets containing different levels of Spirulina platensis. Bioresource Technology 80, 117-120.

Olvera-Novoa, M.A., Domínguez-Cen, L.J., Olivera-Castillo, L. et al. (1998). Effect of the use of the microalga Spirulina maxima as fishmeal replacement in diets for tilapia, Oreochromis mossambicus (Peters), fry. Aquaculture Research 29, 709-715.

Palmegiano, G.B., Agradi, E., Forneris, G., et al. (2005). Spirulina as a nutrient source in diets for growing sturgeon (Acipenser baeri). Aquaculture Research 36, 188-195.

Phumee, P., Wei W. Y., Ramachandran, S. \& Hashim, R. (2011). Evaluation of soybean meal in the formulated diets for juvenile Pangasianodon hypophthalmus (Sauvage, 1878). Aquaculture Nutrition 17, 214-222.

Qin, J. G., Mittiga, L. \& Ottolenghi, F. (2004). Cannibalism reduction in juvenile barramundi Lates calcarifer by providing refuges and low light. Journal of the World Aquaculture Society 35(1),113-118.

Ramakrishnan, C.M., Haniffa, M.A., Manohar, M. et al. (2008). Effects of probiotic and spirulina on survival and growth of juvenile common carp (Cyprinus carpio). The Israeli Journal of Aquaculture - Bamidgeh 60, 128-133.

Richmond, A. (1988). Spirulina. In: Micro-Algal Biotechnology (M.A. Borowitzka \& L. J. Borowitzka, eds.), pp 85-121. Cambridge University Press, Cambridge

Santillán, S.C. (1979). Progresos con el alga Spirulina en la alimentación de animales y humanos. VIII Congreso Interamericano de Ingeniería Química, Bogotá, Colombia. August, 1979. Mimeography

Schmidt-Nielsen, K. (1997). Water and osmotic regulation. In: Animal Physiology Adaptation and Environment, fifth edition (K. SchmidtNielsen, ed.), pp 301- 354. Cambridge University Press

Smith, N.F., Talbot, C. \& Eddy, F.B. (1989). Dietary salt intake and its relevance to ionic regulation in freshwater salmonids. Journal of Fish Biology 35, 749- 753.

Tongsiri, S., Mang-Amphan, K. \& Peerapornpisal, Y. (2010). Effect of Replacing Fishmeal with Spirulina on Growth, Carcass Composition and Pigment of the Mekong Giant Catfish. Asian Journal of Agricultural Sciences 2, 106-110.

Watanabe, T., Liao, W.L., Takeuchi, T. et al. (1990). Effect of dietary Spirulina supplementation on growth performance and flesh lipids of cultured striped jack. Journal of the Tokyo University of Fisheries 77, 231-239

Woods, T. A. (1999). Largemouth bass - Production budget. Commonwealth of Kentucky Aquaculture Plan, Frankfort, Kentucky, USA

Zaugg, W.S., Roley, D.D., Prentice, E.F. et al. (1983). Increased seawater survival and contribution to the fishery of Chinook salmon (Oncorhynchus tshawytscha) by supplemented dietary salt. Aquaculture 32, 183-188.

Zhou, Q.C., Tan, B.P., Mai, K.S. et al. (2004). Apparent digestibility of selected feed ingredients for juvenile cobia Rachycentron canadum. Aquaculture 241, 441-451. 